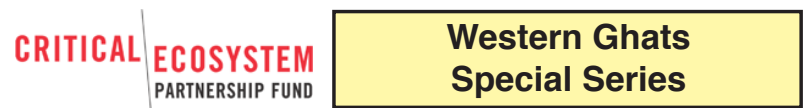

\title{
Checklist of the fishes of the Achankovil forests, Kerala, India with notes on the range extension of an endemic cyprinid Puntius chalakkudiensis
}

\author{
Fibin Baby ${ }^{1}$, Josin Tharian ${ }^{2}$, Siby Philip ${ }^{3}$, Anvar Ali ${ }^{4}$ \& Rajeev Raghavan ${ }^{5}$ \\ 1,2,4,5 Conservation Research Group (CRG), St. Albert's College, Kochi, Kerala 682018, India \\ ${ }^{2}$ Department of Zoology and Environmental Sciences, St. John's College, Anchal, Kerala 691306, India \\ ${ }^{3}$ Centro Interdisciplinar de Investigação Marinha e Ambiental, University of Porto, Portugal \\ ${ }^{5}$ Durrell Institute of Conservation and Ecology (DICE), School of Anthropology and Conservation, University of Kent, Canterbury \\ CT2 7NZ, United Kingdom \\ Email: ${ }^{1}$ fibinaqua@gmail.com, ${ }^{2}$ josinc@gmail.com, ${ }^{3}$ philipsiby@gmail.com, ${ }^{4}$ anvaraliif@gmail.com, ${ }^{5}$ rajeevraq@hotmail.com \\ (corresponding author)
}

Located in the Periyar-Agasthyamalai corridor (CEPF 2007), the Achankovil Reserve Forests (ARF) $\left(269 \mathrm{~km}^{2}\right)$, comprising of dry deciduous, moist deciduous and evergreen forests is a priority site for conservation in the southern Western Ghats (CEPF 2007). The area is bounded by Tamil Nadu State in the east, Ranni forest division in the northeast, Konni forest division in the west, Punalur forest division in the

Date of publication (online): 26 July 2011

Date of publication (print): 26 July 2011

ISSN 0974-7907 (online) | 0974-7893 (print)

Editor: K. Rema Devi

Manuscript details:

Ms \# 02674

Received 12 January 2011

Final received 23 June 2011

Finally accepted 06 July 2011

Citation: Baby, F., J. Tharian, S. Philip, A. Ali \& R. Raghavan (2011) Checklist of the fishes of the Achankovil forests, Kerala, India with notes on the range extension of an endemic cyprinid Puntius chalakkudiensis. Journal of Threatened Taxa 3(7): 1936-1941

Copyright: (C Fibin Baby, Josin Tharian, Siby Philip, Anvar Ali \& Rajeev Raghavan 2011. Creative Commons Attribution 3.0 Unported License. JoTT allows unrestricted use of this article in any medium for non-profit purposes, reproduction and distribution by providing adequate credit to the authors and the source of publication.

Acknowledgements: Funding for the study came from the Critical Ecosystem Partnership Fund (CEPF) Western Ghats Program through the Ashoka Trust for Research in Ecology and Environment (ATREE), Bengaluru, India. The authors thank the Principal Chief Conservator of Forests and Chief Wildlife Warden, Government of Kerala for permits; Rateesh and Prasobh for their assistance in the field, and M.R. Ramprasanth for his support in the laboratory. Thanks are also due to Ralf Britz (British Museum of Natural History, London) and Rema Devi (Zoological Survey of India, Chennai) for their help during the examination of the types.

OPEN ACGESS | FREE DOWNLOAD
Abstract: We report the results of an ichthyofaunal inventory carried out in the Achankovil Reserve Forest in the southern Western Ghats as part of a Critical Ecosystem Partnership Fund Project on lesser known freshwater fishes of Kerala . Forty-six species of freshwater fish, belonging to 17 families and 31 genera were collected from 11 sites inside the Achankovil Reserve Forest. Family Cyprinidae dominated with 21 species, followed by Bagridae, Balitoridae and Channidae (three species each). Out of the 46 species, 14 were endemic to the Western Ghats, three were endemic to Kerala region and one was exotic to the country. In this paper, we also report the range extension of an endemic cyprinid, Puntius chalakkudiensis to the Achankovil River and the Achankovil Reserve Forest. The fish diversity of this region is higher than many protected areas within southern Western Ghats, and stresses the need for immediate protection and monitoring programs.

Keywords: Achankovil forests, freshwater fish, Puntius chalakkudiensis, range extension

southwest, and Thenmala forest division in the south (Hosagoudar et al. 2010). Achankovil RF is drained by the river Achankovil and its major tributaries Kanayar, Kallar, Chittar and Kakkadyaar. Preliminary studies have revealed that this region harbours around 96 species of birds, 13 species of mammals, 12 species of reptiles and four species of amphibians (Kalesh et al. 2010).

Although a few studies are available on the fish

This article forms part of a special series on the Western Ghats of India, disseminating the results of work supported by the Critical Ecosystem Partnership Fund (CEPF), a joint initiative of l'Agence Française de Développement, Conservation International, the Global Environment Facility, the Government of Japan, the MacArthur Foundation and the World Bank. A fundamental goal of CEPF is to ensure civil society is engaged in biodiversity conservation. Implementation of the CEPF investment program in the Western Ghats is led and coordinated by the Ashoka Trust for Research in Ecology and the Environment (ATREE). 

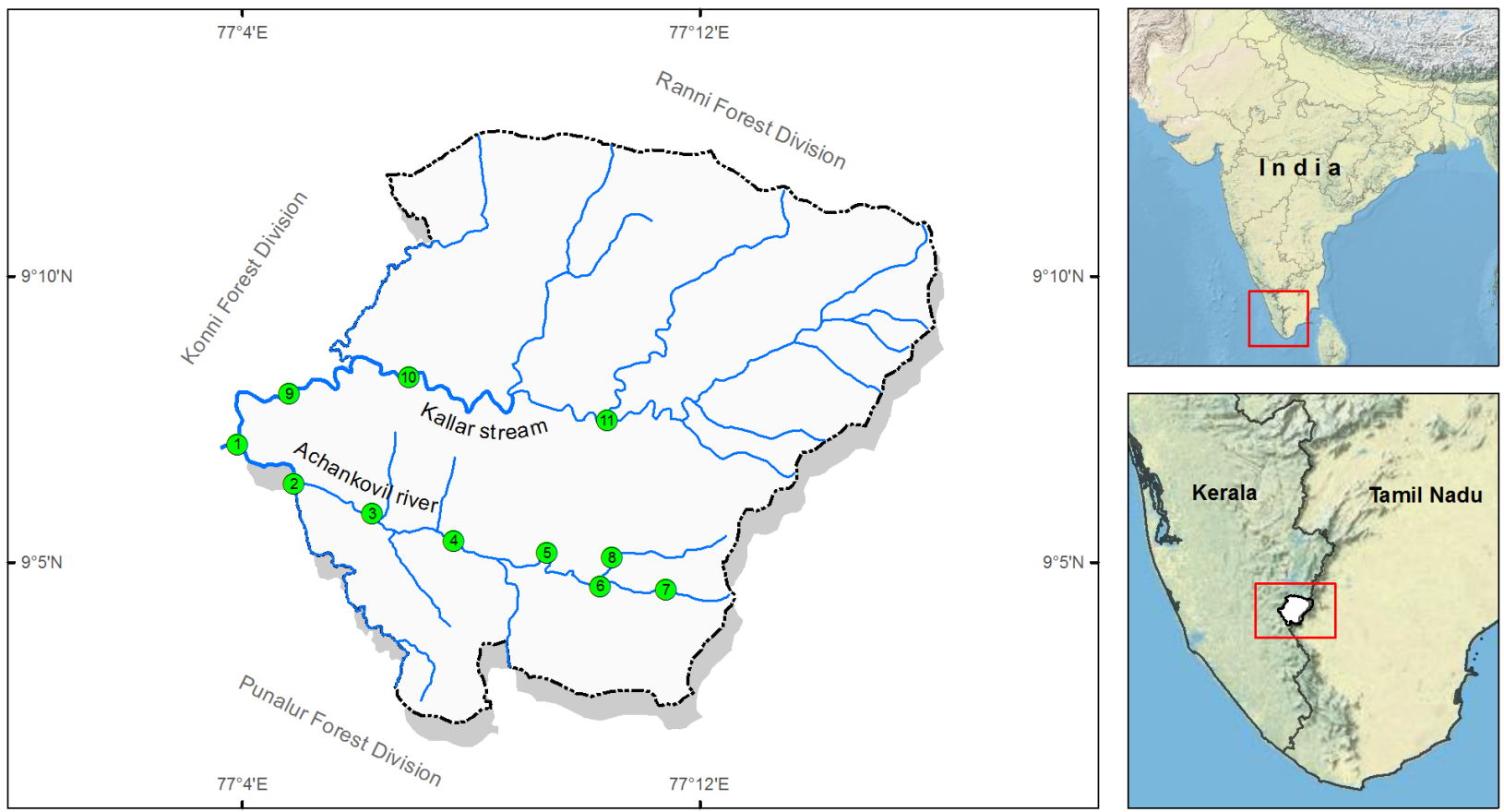

A Sampling Stations $\sim$ Rivers and Streams Political Boundary

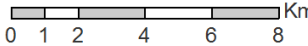

Image 1. Map of Achankovil Reserve Forest showing sampling sites

Table 1. Details of sampling sites in Achankovil Reserve Forest

\begin{tabular}{|c|l|c|c|c|}
\hline No & Site & $\begin{array}{c}\text { Latitude } \\
\text { N }\end{array}$ & $\begin{array}{c}\text { Longitude } \\
\mathbf{E}\end{array}$ & $\begin{array}{c}\text { Altitude } \\
(\mathbf{m})\end{array}$ \\
\hline 1 & Mukkada & 9.118 & 77.065 & 58 \\
\hline 2 & Chittar & 9.106 & 77.082 & 60 \\
\hline 3 & Mlaankuzhi & 9.098 & 77.104 & 62 \\
\hline 4 & Achankovil & 9.090 & 77.128 & 74 \\
\hline 5 & Pallivasal & 9.086 & 77.155 & 110 \\
\hline 6 & Madandachappath & 9.076 & 77.172 & 122 \\
\hline 7 & Manalar & 9.075 & 77.190 & 146 \\
\hline 8 & Kumbaratty & 9.085 & 77.174 & 166 \\
\hline 9 & Kadakkola & 9.133 & 77.080 & 104 \\
\hline 10 & Panamthoppu & 9.137 & 77.115 & 134 \\
\hline 11 & Kallar & 9.125 & 77.171 & 208 \\
\hline
\end{tabular}

diversity of Achankovil River system (Varghese 1994; Swapna 2009), micro-level species distribution data are restricted to sites in the midland and lowland areas. To the best of our knowledge, there is detailed information on the ichthyodiversity of only one location inside the Achankovil forests i.e. Achankovil (Varghese 1994).

As part of a larger project that is aimed at generating baseline data on the fish fauna of lesser known areas in the southern Western Ghats (CEPF-ATREE 2010), we carried out an ichthyofaunal inventory at various sites inside the ARF, at multiple intervals in 2010. This contribution provides a checklist of the freshwater fish fauna of this region, with notes on the range extension of an endemic species Puntius chalakkudiensis.

Taking into consideration, the costs and logistics, we used a rapid assessment approach (Abd et al. 2009). Dawn (0500-0800 hr), daytime (0800-1730 hr), dusk (1730-1930 hr) and night (1930-0500 hr) sampling were carried out at 11 sites in the various tributaries draining the Achankovil forests (Image 1 and Table 1). Although electrofishing (using a backpack electroshocker) was the primary technique used for fish collection, we also employed a diverse array of active as well as passive gear including cast net, scoop net, drag net, gill net and traps. This was because of the fact that electrofishing is considered to be the most effective sampling method for stream fishes, especially when sampling species that are at risk (Poos et al. 2007). The other gears were used so as to avoid sampling bias in specific habitats (for example, torrential stream reaches and large cascades) where electrofishing was not possible. The use of an electroshocker also meant that we only collected the minimum number of specimens as required for 
Table 2. List of species and their micro level distribution in Achankovil Forests

\begin{tabular}{|c|c|c|}
\hline & Species & Locations \\
\hline & Cyprinidae & \\
\hline 1 & $\begin{array}{l}\text { Amblypharyngodon microlepis } \\
\text { (Bleeker, 1854) }\end{array}$ & 6 \\
\hline 2 & $\begin{array}{l}\text { Barbodes carnaticus (Jerdon, } \\
\text { 1849) EWG }\end{array}$ & 6 \\
\hline 3 & Barilius bakeri Day, $1865^{\text {Ewg }}$ & $\begin{array}{l}1,2,3,4,5,6,8,9 \\
10,11\end{array}$ \\
\hline 4 & $\begin{array}{l}\text { Barilius gatensis (Valenciennes, } \\
\text { 1844) }\end{array}$ & $\begin{array}{l}1,2,3,4,5,6,8,9 \\
10,11\end{array}$ \\
\hline 5 & $\begin{array}{l}\text { Devario malabaricus (Jerdon, } \\
\text { 1849) }\end{array}$ & $\begin{array}{l}1,2,3,4,5,6,7,8,9 \\
10,11\end{array}$ \\
\hline 6 & Garra mullya (Sykes, 1839) & $\begin{array}{l}1,2,3,4,5,6,7,8,9 \\
10,11\end{array}$ \\
\hline 7 & $\begin{array}{l}\text { Garra surendranathanii Shaji, } \\
\text { Arun \& Easa, 1996 EK }\end{array}$ & 1,9 \\
\hline 8 & $\begin{array}{l}\text { Hypselobarbus curmuca } \\
\text { (Hamilton, 1807) EWG }\end{array}$ & 5 \\
\hline 9 & Laubuca fasciata (Silas, 1958) ЕК & $2,3,4,5$ \\
\hline 10 & $\begin{array}{l}\text { Puntius amphibius } \\
\text { (Valenciennes, 1842) }\end{array}$ & 1 \\
\hline 11 & $\begin{array}{l}\text { Puntius bimaculatus (Bleeker, } \\
\text { 1863) }\end{array}$ & 8,9 \\
\hline 12 & $\begin{array}{l}\text { Puntius chalakkudiensis Menon } \\
\text { et al., } 1999 \mathrm{EK}\end{array}$ & 1,9 \\
\hline 13 & Puntius denisonii (Day, 1865) EWG & 1,9 \\
\hline 14 & $\begin{array}{l}\text { Puntius fasciatus (Jerdon, } \\
\text { 1849) }\end{array}$ & $\begin{array}{l}1,2,3,4,5,6,7,8,9 \\
10,11\end{array}$ \\
\hline 15 & $\begin{array}{l}\text { Puntius filamentosus } \\
\text { (Valenciennes, 1844) }\end{array}$ & $\begin{array}{l}1,2,3,4,5,6,7,8,9 \\
10,11\end{array}$ \\
\hline 16 & Puntius sarana (Hamilton, 1822) & 1,9 \\
\hline 17 & Puntius ticto (Hamilton, 1822) & $1,9,10$ \\
\hline 18 & Puntius vittatus Day, 1865 & 1,10 \\
\hline 19 & $\begin{array}{l}\text { Rasbora daniconius (Hamilton- } \\
\text { Buchanan) }\end{array}$ & $\begin{array}{l}1,2,3,4,5,6,7,8 \\
9,10\end{array}$ \\
\hline 20 & $\begin{array}{l}\text { Salmophasia boopis (Day, } \\
\text { 1874) }\end{array}$ & $1,2,3,4,9$ \\
\hline \multirow[t]{2}{*}{21} & Tor khudree (Sykes, 1839) & 9 \\
\hline & Balitoridae & \\
\hline 22 & $\begin{array}{l}\text { Bhavania australis (Jerdon, } \\
\text { 1849) EWG }\end{array}$ & $1,6,11$ \\
\hline 23 & $\begin{array}{l}\text { Nemacheilus triangularis Day, } \\
1865 \text { EWG }\end{array}$ & $\begin{array}{l}1,2,3,4,5,6,7,8,9 \\
10,11\end{array}$ \\
\hline \multirow[t]{2}{*}{24} & $\begin{array}{l}\text { Nemacheilus guentheri Day, } \\
1867 \text { EwG }\end{array}$ & $6,7,9,10$ \\
\hline & Cobitidae & \\
\hline \multirow[t]{2}{*}{25} & $\begin{array}{l}\text { Lepidocephalichthys thermalis } \\
\text { (Valenciennes, 1846) }\end{array}$ & $\begin{array}{l}1,2,3,4,5,6,7,8,9 \\
10,11\end{array}$ \\
\hline & Bagridae & \\
\hline 26 & Mystus armatus (Day, 1865) & 1 \\
\hline 27 & $\begin{array}{l}\text { Mystus cavasius (Hamilton, } \\
1822 \text { ) }\end{array}$ & 1,10 \\
\hline
\end{tabular}

\begin{tabular}{|c|c|c|}
\hline & Species & Locations \\
\hline \multirow[t]{2}{*}{28} & $\begin{array}{l}\text { Mystus malabaricus (Jerdon, } \\
\text { 1849) EWG }\end{array}$ & $4,5,6$ \\
\hline & Siluridae & \\
\hline \multirow[t]{2}{*}{29} & $\begin{array}{l}\text { Ompok bimaculatus (Bloch, } \\
\text { 1794) }\end{array}$ & 7 \\
\hline & Sisoridae & \\
\hline \multirow[t]{2}{*}{30} & $\begin{array}{l}\text { Glyptothorax cf. anamalaiensis } \\
\text { (Silas, 1952) EWG }\end{array}$ & 9 \\
\hline & Heteropneustidae & \\
\hline \multirow[t]{2}{*}{31} & $\begin{array}{l}\text { Heteropneustes fossilis (Bloch, } \\
\text { 1794) }\end{array}$ & 2,3 \\
\hline & Belonidae & \\
\hline \multirow[t]{2}{*}{32} & $\begin{array}{l}\text { Xenentodon cancila (Hamilton, } \\
\text { 1822) }\end{array}$ & 1,9 \\
\hline & Aplocheilidae & \\
\hline \multirow[t]{2}{*}{33} & $\begin{array}{l}\text { Aplocheilus lineatus } \\
\text { (Valenciennes, 1846) }\end{array}$ & $4,5,6,11$ \\
\hline & Ambassidae & \\
\hline 34 & $\begin{array}{l}\text { Parambassis dayi (Bleeker, } \\
\text { 1874) EWG }\end{array}$ & $1,9,10$ \\
\hline \multirow[t]{2}{*}{35} & $\begin{array}{l}\text { Pseudambassis baculis } \\
\text { (Hamilton, 1822) }\end{array}$ & 1 \\
\hline & Nandidae & \\
\hline 36 & $\begin{array}{l}\text { Nandus nandus (Hamilton, } \\
1822 \text { ) }\end{array}$ & 1 \\
\hline \multirow[t]{2}{*}{37} & $\begin{array}{l}\text { Pristolepis marginata Jerdon, } \\
1849\end{array}$ & 4,5 \\
\hline & Cichlidae & \\
\hline 38 & $\begin{array}{l}\text { Etroplus maculatus (Bloch, } \\
1795)\end{array}$ & $1,9,10$ \\
\hline \multirow[t]{2}{*}{39} & $\begin{array}{l}\text { Oreochromis mossambicus, } \\
\text { (Peters 1852) Ex }\end{array}$ & 1 \\
\hline & Gobiidae & \\
\hline \multirow[t]{2}{*}{40} & $\begin{array}{l}\text { Glossogobius giuris (Hamilton, } \\
\text { 1822) }\end{array}$ & $2,3,10$ \\
\hline & Anabantidae & \\
\hline \multirow[t]{2}{*}{41} & $\begin{array}{l}\text { Anabas testudineus (Bloch, } \\
\text { 1792) }\end{array}$ & 1 \\
\hline & Channidae & \\
\hline 42 & $\begin{array}{l}\text { Channa marulius (Hamilton, } \\
\text { 1822) }\end{array}$ & 1,10 \\
\hline 43 & Channa striatus (Bloch, 1793) & 9 \\
\hline \multirow[t]{2}{*}{44} & $\begin{array}{l}\text { Channa gachua (Hamilton, } \\
\text { 1822) }\end{array}$ & 4 \\
\hline & Osphronemidae & \\
\hline \multirow[t]{2}{*}{45} & $\begin{array}{l}\text { Pseudosphromenus } \\
\text { cupanus (Cuvier, 1831) }\end{array}$ & 1,10 \\
\hline & Mastacembelidae & \\
\hline 46 & $\begin{array}{l}\text { Mastacembelus armatus } \\
\text { (Lacepède, 1800) }\end{array}$ & $1,2,4,5,9$ \\
\hline
\end{tabular}

EWG - Endemic to Western Ghats; EK - Endemic to Kerala; Ex - Exotic to the country 




Image 2. Puntius chalakkudiensis (Menon, Devi \& Thobias 1999)

our study (especially threatened and restricted range endemics). Species level identification was carried out following Jayaram (1999) and Talwar \& Jhingran (1991) and species names adhere to the CAS - Catalog of Fishes (Eschemeyer 2010).

Forty-six species $(S=46)$ belonging to 17 families and 31 genera were collected from various sites inside the ARF (Table 2). Family Cyprinidae dominated with 21 species $(S=21)$ followed by Bagridae $(S=3)$, Balitoridae $(\mathrm{S}=3)$ and Channidae $(\mathrm{S}=3)$. Out of the 46 species, 14 are endemic to the Western Ghats, of which three species (Garra surendranathanii, Laubuca fasciata and Puntius chalakkudiensis) are endemic to the Kerala region. One species (Oreochromis mossambicus) is exotic to the country.

Swapna (2009) recorded 52 species including 39 typical freshwater and three typical marine fish species from four sites spread across the upstream-downstream gradient of river Achankovil, while Varghese (1994) recorded 64 species from the Achankovil drainage, including a dozen marine and brackish water forms. Surprisingly, Neelakandan et al. (2006) indicated that only 10 fish species are found in the Achankovil river basin. Our results of the occurrence of 46 species inside the ARF could only mean that the overall ichthyodiversity of the Achankovil river system is much more than what has been recorded by earlier workers including Swapna (2009) and Varghese (1994).

Within the ARF, two sites, Mukkada and Kadakkola had the highest species richness with the presence of 30 and 24 species respectively, while the lowest richness of nine species was found at Manalar. Johnson \& Arunachalam (2009) recorded 17 species from a site which they named as Achankovil (with the coordinates $9^{0} 10^{\prime} 12^{\prime \prime} \mathrm{N} \& 76^{0} 50^{\prime} 28^{\prime \prime} \mathrm{E} / 9.17 \mathrm{~N} \&$ 76.481E). However, this site (according to the Survey of India Toposheet 58C 16 and 58G 4, Scale 1:50,000 and Google Earth) falls far from Achankovil town (and also out of the Achankovil RF). Therefore, we have not compared the fish diversity of Achankovil town obtained in our study with that of Johnson \& Arunachalam (2009).

The presence of the alien invasive Oreochromis mossambicus at Mukkada, the site with the highest species richness, is a plausible threat to the endemic species of the region. Taking into consideration the trophic status of $O$. mossambicus, we believe that an immediate threat to a native species would be to the orange chromide Etroplus maculatus, a sizeable population of which occurs at Mukkada. An important native ornamental fish, as well as a popular food fish with low income groups, E. maculatus shares more or less the same resources as that of $O$. mossambicus and so the proliferation of the former will invariably harm the native stocks of the orange chromide (Raghavan et al. 2008a).

The present study has also resulted in the range extension of an endemic fish species of Kerala, P. chalakkudiensis (Image 2) to the ARF (and the Achankovil river system). Puntius chalakkudiensis, a look alike of the popular aquarium fish, $P$. denisonii was previously thought to be endemic to the Chalakudy River (Menon et al. 1999; Kurup et al. 2004). Our surveys in Achankovil RF indicated that the streams harbour good populations of $P$. chalakkudiensis, which are consumed as a food fish by the local tribes. We recorded more than 380 individuals of P. chalakkudiensis over a one year period (20092010) from two sites, Mukkada and Kadakkola as 
part of another study on the population status of this species in the Achankovil River. All individuals were collected using a backpack electroshocker and were released after taking the length and weight. We also compared in detail 10 specimens (40-104 mm SL) of $P$. chalakkudiensis from Achankovil, to those collected by us from the type locality of the species (Athirapally in Chalakudy River) and currently stored at the Museum of the Department of Aquaculture, St. Albert's College, Kochi, India (CRG-SAC-897.1 and 897.2) and found that all of them matched the original description of P. chalakkudiensis (Menon et al. 1999), in its morphology, including the distinct black blotch on the dorsal fin and inferior mouth. The specimens of $P$. denisonii recorded from Achankovil were also compared to the type material of $P$. denisonii at the British Museum of Natural History, London (BMNH 1864.7.9.6 and BMNH 1866.5.2.211).

Many authors including Kurup et al. (2004), Johnson \& Arunachalam (2009) and Swapna (2009) have recorded only P. denisonii from Achankovil River. However, our study has revealed that both $P$. denisonii and $P$. chalakkudiensis are found in the Achankovil River and that they co-exist in the same habitat.

We collected one specimen of a sisorid catfish that resembled Glyptothorax anamalaiensis in its appearance but had some minor differences. The biometrics of this specimen was compared with that of another specimen of $G$. anamalaiensis collected from the Anamalai Hills near Valparai and deposited at the Museum of the Conservation Research Group, St. Albert's College, Kochi (CRG-SAC 167). As a comprehensive and reliable taxonomical key is not available for the species within the genus Glyptothorax found in the Western Ghats, we have retained the species as Glyptothorax cf. anamalaiensis in the current checklist, and it is being subjected to detailed taxonomical investigation.

Kalesh et al. (2010) observed that the major threats to the Achankovil RF are logging for softwood industry, harvesting of endemic reeds and indiscriminate fishing. We found that dynamiting is one of the major threats to the fishes of the ARF. Members of the local community residing in the settlements in and around Achankovil visit the deep pools in and around Mukkada and Kadakkola, as well as various other locations in the Kallar tributary to catch fish using dynamite purchased from quarries. Dynamite fishing has been documented from the southern WG since the early 1940s (Jones 1946) and continues to be one of the most widely used destructive fishing techniques practiced in the region (Kurup et al. 2004; Raghavan et al. 2008b). Although dynamite fishing has been banned vide the Travancore Cochin Fisheries Act of 1950 (Government of Kerala, India) there is very little or no enforcement from the concerned authorities, and the practice continues to exist even inside reserve forests and protected areas of the region.

The fact that the fish diversity of Achankovil RF $(\mathrm{S}=46)$ is higher than many protected areas in the region including the Neyyar $(\mathrm{S}=38)$ and Idukki $(\mathrm{S}=40)$ wildlife sanctuaries (Thomas et al. 2000) stresses the need for increased protection and monitoring programs in this area. The Western Ghats Ecosystem Profile prepared as part of the Critical Ecosystem Partnership Fund Program (CEPF 2007) suggested that ARF is a site that warrants immediate attention in terms of setting up mechanisms for their incorporation into the protected area network. Our results on the fish fauna of the region further confirm this need.

\section{REFERENCES}

Abd, I.M., C. Rubec \& B.W. Coad (2009). Key Biodiversity Areas: rapid assessment of fish fauna in southern Iraq. BioRisk 3: 161-171.

CEPF-ATREE (2010). http://www.atree.org/cepf_small_ grants. Accessed on 21st June 2010

CEPF (2007). Critical Ecosystem Partnership Fund Ecosystem Profile: Western Ghats and Sri Lanka Biodiversity Hotspot - Western Ghats region, 95pp

Eschmeyer, W.N. (ed.) (2010). Catalog of fishes electronicversion. http://research.calacademy.org/ ichthyology/catalog/fishcatmain.asp. Accessed on 24 June 2010

Jayaram, K.C. (1999). The Freshwater Fishes of The Indian Region. Narendra Publishing House, New Delhi, 396pp.

Hosagoudar, V.B., P.J. Robin \& B. Shivaraju (2010). Foliicolous fungi from the Achankovil forests in Kollam District of Kerala State, India. Journal of Threatened Taxa 2(3): 760-761.

Johnson, J \& M. Arunachalam (2009). Diversity, distribution and assemblage structure of fishes in streams of southern Western Ghats, India. Journal of Threatened Taxa 1(10): 507-513.

Jones, S. (1946). Destructive methods of fishing in the rivers of the hill ranges of Travancore. Journal of the Bombay Natural History Society 46: 437-445.

Kalesh, S., K.B. Sanjayan, K. Jayakumar, M. Ramesh, C.G. 
Kiran, H. Charan \& K. Baiju (2010). The faunal diversity of Achankovil Reserve forests: a preliminary study report. Travancore Natural History Society. http://info-tnhs. blogspot.com/2010/09/faunal-diversity-of-achankovilreserve.html

Kurup B.M, K.V. Radhakrishnan \& T.G. Manojkumar (2004). Biodiversity status of fishes inhabiting rivers of Kerala (s. India) with special reference to endemism, threats and conservation measures, pp. 163-182. In: Welcome, R.L. \& T. Petr (eds.). Proceedings of LARS2. $2^{\text {nd }}$ Large Rivers Symposium. Mekong River Commission and Food and Agricultural Organization.

Menon, A.G.K., K.R. Devi \& M.P. Thobias (1999). Puntius chalakkudiensis, a new colourful species of Puntius (family: Cyprinidae) fish from Kerala, south India. Records of the Zoological Survey of India 97(4): 61-63.

Neelakandan, V.N., C.N. Mohanan \& B. Sukumar (2006). Development of a biogeographical information system for conservation monitoring of biodiversity. Current Science 90(3): 444-450.

Poos, M.S., N.E. Mandrak \& R.L. McLaughlin (2007). The effectiveness of two sampling methods for assessing imperiled freshwater fishes. Journal of Fish Biology 70: 691-708.
Raghavan, R., G. Prasad, P.H.A. Ali \& B. Pereira (2008a). Exotic fish species in a Biodiversity Hotspot: observations from the River Chalakudy, part of Western Ghats, Kerala, India. Biological Invasions 10: 37-40.

Raghavan R., G. Prasad, P.H.A. Ali \& B. Pereira (2008b). Fish fauna of River Chalakudy part of Western Ghats biodiversity hotspot (south India) - patterns of distribution, threats and conservation needs Biodiversity and Conservation 17: 3119-3131.

Talwar, P.K. \& A.G. Jhingran (1991). Inland Fishes of India and Adjacent Countries, Vol I \& II. Oxford \& IBH Publishing Co. Pvt. Ltd., New Delhi, 1158pp.

Thomas, K.R., C.R. Biju, C.R. Ajithkumar \& M.J. George (2000). Fish fauna of Idukki and Neyyar Wildlife Sanctuaries, Southern Kerala, India. Journal of the Bombay Natural History Society 97(3): 443-446.

Swapna, S. (2009). Fish diversity in Achankovil River, Kerala, India. Journal of the Bombay Natural History Society 106(1): 104-106.

Varghese, J.G (1994). Studies on fish assemblages in the Achankovil river system with special reference to their niche segregation and habitat usage. PhD Thesis. Mahatma Gandhi University, Kottayam, India (unpublished). 